\title{
Influence of Solvents on Protolytic and Aggregation Properties of Aminomethylated Calix[4]resorcine
}

\author{
E. V. Guseva, ${ }^{a}$ T. M. Buslaeva, ${ }^{\mathrm{b}}$ E. I. Grishin, ${ }^{\mathrm{a}}$ and T. T. Zinkicheva ${ }^{\mathrm{a}}$ \\ ${ }^{a}$ Kazan National Research Technological University, 420015 Kazan, Russian Federation \\ ${ }^{\mathrm{b}}$ Moscow Technological University (Institute of Fine Chemical Technology), 119454 Moscow, Russian Federation \\ ${ }^{\circledR}$ Corresponding author E-mail: leylaha@mail.ru
}

\begin{abstract}
Methods of pH-metry and quantum-chemical modeling were used to study the protolytic properties of calix[4]resorcine aminomethylated at the lower rim in $\mathrm{H}_{2} \mathrm{O}, \mathrm{EtOH}, \mathrm{Me}_{2} \mathrm{CO}$. Preferential protonation of the lower rim amino groups and dissociation of the hydroxyl group of the upper rim that determines its self-association of the type "head to tail" due to electrostatic forces have been shown. Using electron spectroscopy, conductometry and dynamic light scattering it has been found that strong ionizing properties of $\mathrm{Me}_{2} \mathrm{CO}$ and $\mathrm{H}_{2} \mathrm{O}$ facilitate the formation of two-component assemblies with the participation of solvent molecules. The tendency for the formation of intermolecular hydrogen bonds between the molecules of the solvent promotes the formation of a homogeneous monodisperse environment for EtOH. Nonaqueous medium contributes to the consolidation of associates of aminomethylated calix[4]resorcine.
\end{abstract}

Keywords: Aminomethylated calix[4]resorcine, self-association, aggregation.

\section{Влияние растворителей на протолитические и агрегационные свойства аминометилированного каликс[4]резорцина}

\author{
Е. В. Гусева, ${ }^{a}{ }^{@}$ Т. М. Буслаева, ${ }^{\mathrm{b}}$ Е. И. Гришин, ${ }^{\mathrm{a}}{ }$ T. Т. Зинкичева ${ }^{\mathrm{a}}$ \\ ${ }^{a}$ Казанский национальный исследовательский технологический университет, 420015 Казань, Россия \\ ${ }^{\mathrm{b}}$ Московский государственный университет тонких химических технологий им. М.В. Ломоносова, 119571 Москва, \\ Россия \\ @E-mail:leylaha@mail.ru
}

\begin{abstract}
Методами рН-метрии и квантовохимического моделирования изучены протолитические свойства аминометилированного по нижнему ободу каликс[4]резориина в $\mathrm{H}_{2} \mathrm{O}$, EtOH, Me ${ }_{2} \mathrm{CO}$. Показаны преимущественное протонирование аминогрупп нижнего обода и диссоииация гидроксигрупп верхнего обода, обусловливающуие его самоассоциацию по типу «голова к хвосту» за счет электростатических сил. С использованием электронной спектроскопии, кондуктометрии и динамического светорассеяния установлено, что сильнье ионизирующие свойства Ме $\mathrm{CO}_{2} \mathrm{H}_{2} \mathrm{O}$ способствуют образованию двухкомпонентных агрегатов с участием молекул растворителей. Склонность к образованию межмолекулярных водородных связей между молекулами растворителя способствует образованию однородной монодисперсной среды для ЕtОН. Неводная среда способствуют укрупнению ассоциатов аминометилированного каликс[4]-резорична.
\end{abstract}

Ключевые слова: Аминометилированный каликс[4]резорцин, самоассоциация, агрегация. 


\section{Introduction}

In a series of macrocyclic hollow systems one of the most promising objects are calix[4]resorcines characterized by the ability to molecular recognition and self-association. ${ }^{[1,2]}$ They are of interest as new types of catalysts, ${ }^{[3-6]}$ selective sorbents of molecules and ions, ${ }^{[7,8]}$ sensors, ${ }^{\left[{ }^{[3]}\right.}$ bioregulators. ${ }^{[10]}$

Earlier ${ }^{[11-13]}$ we have described the complexing properties of aminomethylated calix[4]resorcines $(\mathbf{L}, \mathbf{L 1})$ relative to the ions of $\mathrm{Rh}^{\mathrm{III}}$ and $\mathrm{Pt}^{\mathrm{IV}}$ :

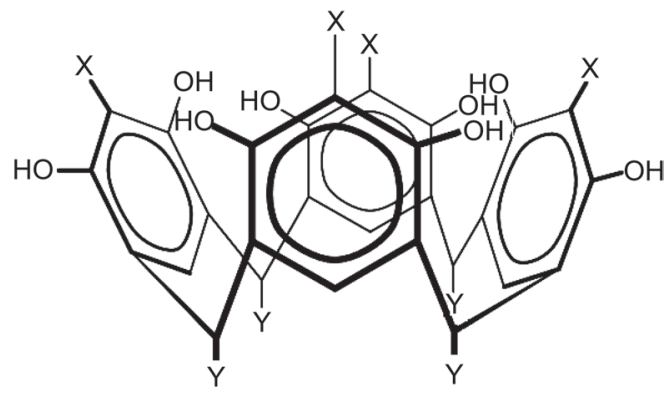

a) $\mathbf{L}: \mathrm{Y}=\mathrm{Ar}-\mathrm{N}(\mathrm{Me})_{2}, \mathrm{X}=\mathrm{H}$; b) L1: $\mathrm{Y}=\mathrm{Ar}, \mathrm{X}=\mathrm{CH}_{2}-\mathrm{N}(\mathrm{Me})_{2}$; conformation «cone», $-r c c c$ - isomers*

Depending on the solvent used (ethanol or acetone), the complexes of different composition and structure were isolated in the solid phase; but in some case ${ }^{[11-13]}$ complexing was not observed. We believe that this is due to the formation of associates of different - depending on the solvent compositions and structures, as a result of which the donor centers of the molecules - ligands are disabled.

Non-functionalized calix[4]resorcines are multicenter protoliths, with up to eight of acid-base centers. Previously it has been established by potentiometric titration ${ }^{[2,14]}$ that the first four protons are characterized by the value $\mathrm{p} K_{a}$ by two units less than the corresponding value for resorcine ( $\left.\mathrm{p} K_{a}=9.44\right)$; but the other four protons can not be removed even by strong bases. The stability of the structures is due to delocalization of the negative charge, and the correct geometry of the fragments $\mathrm{O}-\mathrm{H}-\mathrm{O} .{ }^{[15]}$

Aminoalkylated calix[4]resorcines are also characterized by the presence of strong intramolecular hydrogen bonds $\mathrm{OH} \cdots \mathrm{N}$ (Figure 1c). ${ }^{[16]}$ This leads to the formation of zwitter-ions within a wide range of $\mathrm{pH}=5-10$; at $\mathrm{pH} \sim 3-5$ there is observed the form protonated at nitrogen atom, and at $\sim \mathrm{p} H>10-$ the phenolate one.

Molecules of calix[4]resorcines are non-planar, having four prochiral centers, and they can exist in the form of different conformers. One of the stable forms is the conformation «armchair».

In this case, the ability to form these complexes will be different from the ability to form complexes of the conformer «cone» due to different abilities depending on the solvent to the formation of zwitter-forms and protonation. The purpose of this work is to establish the nature of the acid-base and aggregation behavior of calix[4]resorcine $\mathbf{L}$ in

* The authors express their gratitude to associate professor, Ph.D. (chemistry) Shatalova N.I. and Professor, Ph.D. (chemistry) Gavrilova E.L. for providing the calix[4]resorcines.

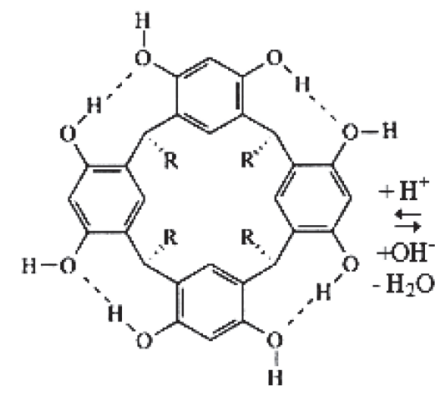

(a)

$$
\mathrm{R}=\mathrm{Me}, \mathrm{Et}(\mathrm{a} ; \mathrm{b})
$$

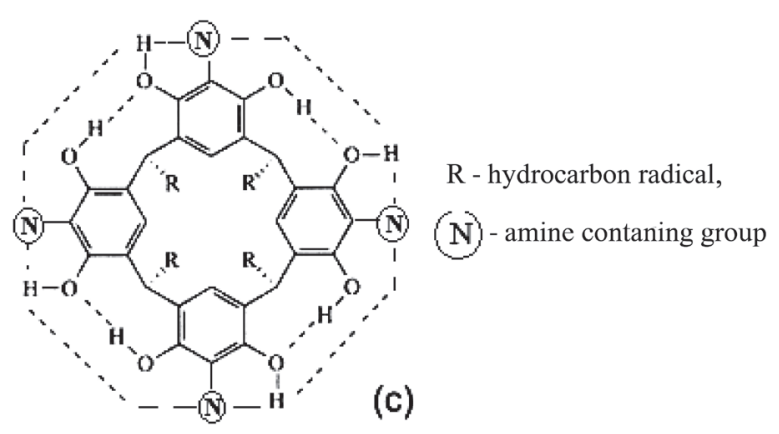

Figure 1. Schematic representation of the hydrogen bonds $\{\mathrm{O} \cdots \mathrm{H} \cdots \mathrm{O}$ and $\mathrm{H} \cdots \mathrm{N} \cdots \mathrm{H}\}$ in the molecules of calix[4]resorcines.

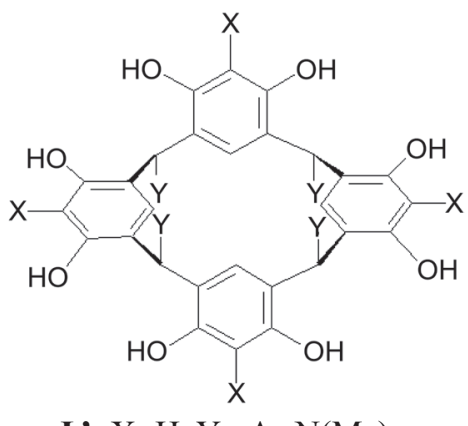

L': $\mathrm{X}=\mathrm{H}, \mathrm{Y}=\operatorname{Ar}-\mathrm{N}(\mathrm{Me})_{2}$; conformation «armchair», -rctt- isomer

water, ethanol and acetone, as well as to evaluate the impact of conformational factors on the various forms formation of calix[4]resorcines $\mathbf{L}$ and $\mathbf{L}$ ' by quantum-chemical modeling methods.

\section{Experimental}

To study the behavior of calix[4]resorcine in a solution we have used the methods of quantum-chemical modeling and $\mathrm{pH}$ metric titration. Quantum chemical calculations were carried out within the framework of density functional theory using a "hybrid" nonlocal functional B3LYP with a gradient of amendments incorporated in the software package "Gaussian- $09 »{ }^{[17]}$ For the description of the valence electrons of the atoms $\mathrm{C}, \mathrm{O}, \mathrm{N}$ and $\mathrm{H}$ the standard basic set D95V was used. ${ }^{[18]}$ It is known from the literature ${ }^{[19,20]}$ that the used basis sets describe well the geometry of the compounds. The geometry of the test structure is optimized without restriction on symmetry. The presence of the minimum energy 
(stationary point) on the potential energy surface was confirmed by the analysis of the calculated frequencies of normal vibrations. Impact of the environment $\left(\mathrm{H}_{2} \mathrm{O}, \mathrm{EtOH}\right.$ and $\left.\mathrm{Me}_{2} \mathrm{CO}\right)$ was taken into account in the model PCM (Polarizable Continuum Model). ${ }^{[17]}$

The solvents used were purified twice by distillation; the other chemicals were of chemical purity classification. Reproducible values of the potentials of the electrodes at a $\mathrm{pH}$-metry and conductimetry were set for 20-30 minutes. For $\mathrm{p} H$-metry we have used $\mathrm{p} H$-meter $« \mathrm{PH}-673 . \mathrm{M} »$, equipped with a glass electrode «ELC-43-07» as an indicator and silver chloride electrode «EVL$1 \mathrm{MZ} »$ as a reference electrode. $\mathrm{pH}$-Metric titration was performed with the continuous supply of titrant and stirring with a magnetic stirrer at $298 \mathrm{~K}$. Pre-sustained in the investigated solvents, the glass electrode was calibrated in these solvents accordingly. ${ }^{[21]}$ Solutions of the compound $\mathbf{L}\left(C=2 \cdot 10^{-3} \mathrm{M}\right)$ were prepared by accurately weighed portion and titrated with an aqueous, ethanol, acetone solutions of potassium hydroxide, free from carbonates. The ionic strength of the solutions was created at the expense of their components.

To identify the nature of the organization of $\mathbf{L}$ in the selected solvents we used the methods of electron spectroscopy, conductometry and dynamic light scattering (DLS). Electronic absorption spectra of the solutions were recorded on a spectrophotometer «SPh-2000» (SDB «SPEKTR», Russia) in the interval 200-800 $\mathrm{nm}, C_{\mathrm{L}}=\left(0.025 \cdot 10^{-3}-0.110 \cdot 10^{-3}\right) \mathrm{M}$, the thickness of the permeable layer $1=1 \mathrm{~cm}$, volume of cuvette $3 \mathrm{ml}$.

The electrical conductivity was measured on the conductometer LM-301 (Standard Cell LM-3000) at 298 K. In the beaker, we placed the working solution with the volume of $10.0 \mathrm{ml}$ at the given concentration of $\mathbf{L}$. After stirring vigorously with a magnetic stirrer for 1 minute, the conductivity of the solution was measured. For zero value there was taken the electrical conductivity used to mix the solvents.

Determination of the $\mathbf{L}$ particle size, formed in water, ethanol, and acetone was carried out using the analyzer of nanoparticles 90Plus/MAS (Firm Brookhaven), laser wavelength $635 \mathrm{~nm}$.

\section{Results and Discussion}

\section{Quantum-Chemical Modeling}

An important instrument for studying the regularities of generating different forms in the solution is quantumchemical modeling.

Previous research of calix[4]resorcine $\mathbf{L} 1$ has shown ${ }^{[12]}$ that in the studied solvents a molecule in a wide range of $\mathrm{pH}=5-10$ has close to zwitterion structure in which a hydrogen ion is collectivized by nitrogen and oxygen atoms. Maximum protonation of nitrogen atoms is an energetically favorable process.

In the case of $\mathbf{L}$, the existence in the form of zwitterion - the transition of protons from hydroxyl groups of resorcinol rings on the amino groups (Figure 1a) - is not supported by the results of calculations in $\mathrm{H}_{2} \mathrm{O}, \mathrm{EtOH}$ and $\mathrm{Me}_{2} \mathrm{CO}$. The thermal effect of transition of four protons from hydroxyl groups of resorcinol rings on the amino groups amounts to $+44,+56,+60 \mathrm{kcal} \cdot \mathrm{mol}^{-1}$ for $\mathrm{H}_{2} \mathrm{O}, \mathrm{EtOH}$ and $\mathrm{Me}_{2} \mathrm{CO}$, respectively. Since ethanol, as a protic solvent, is capable of dissociation with the cleavage of proton, we have investigated

\footnotetext{
** Research on DLS was conducted jointly with the engineer of Management of the preparation and modification of nanoparticles KNRTY Grishin P.V.
}

the protonation of the nitrogen atoms of amino groups for the molecules of $\mathbf{L}$ ( or $\mathbf{L}$ ') according to the scheme:

$$
\mathrm{L}_{\text {solv }}+\mathrm{n} \mathrm{H}_{3} \mathrm{O}_{\text {solv }}^{+} \rightarrow[\mathrm{L} \cdot \mathrm{nH}]^{\mathrm{n}+}{ }_{\text {solv }}+\mathrm{n} \mathrm{H}_{2} \mathrm{O}_{\text {solv }}^{+},
$$

where $\mathrm{n}=1 \div 4$.

According to calculations, the maximum protonation of nitrogen atoms is the most energetically favorable. The thermal effect of the addition reaction of four protons makes up $\sim-37 \mathrm{kcal} \cdot \mathrm{mol}^{-1}$.

To evaluate the effect of conformational factors we have conducted the quantum-chemical modeling of zwitterions formation for $\mathbf{L}$ ' and protonation of nitrogen atoms at the expense of the solvent molecules. Figure $1 \mathrm{~b}$ shows the optimized geometry of $\mathbf{L}$ ' in EtOH. When considering the effect of water and acetone the geometric characteristics of molecules are comparable and vary only slightly.

Investigation of nitrogen atoms protonation in the amino groups of the molecule $\mathbf{L}^{\prime}$ in $\mathrm{H}_{2} \mathrm{O}$ and $\mathrm{EtOH}$ by the scheme (1) has shown that the most energetically favorable process, as well as in the case of molecule $\mathbf{L}$, is the addition of four protons. Heat effects of the reaction (1) involving $\mathbf{L}$ ' are given in Table 1.

Table 1. The thermal effect of the model process (1) for the molecule $\mathbf{L}^{\prime}, \Delta H, \mathrm{kcal} \cdot \mathrm{mol}^{-1}$

\begin{tabular}{ccccc}
\hline The number of protons in $\mathbf{L}^{\prime}$ & 1 & 2 & 3 & 4 \\
\hline water & -28 & -53 & -80 & -104 \\
ethanol & -28 & -52 & -69 & -100 \\
\hline
\end{tabular}

The protonated form of the molecule L' was more stable as compared to the protonated form of the molecule $\mathbf{L}$ (by $\sim 63 \mathrm{kcal} \cdot \mathrm{mol}^{-1}$ ).

To investigate the possible formation of zwitter-form by the molecule L' we have considered two options of proton transfer from oxygen atoms of different hydroxyl groups to nitrogen atoms of amino groups: by the ways 1 and 2 (Figure 2c); the number of protons in this case changed from 1 to 4 . It turned out that the existence of zwitterions is energetically unfavorable by $\sim 20.70 \mathrm{kcal} \cdot \mathrm{mol}^{-1}$. Figure $2 \mathrm{~d}$ shows the dependence of the full energy of zwitterion form of ligand on the number of protons transported by the way 1 (Figure 2c). Protonated forms obtained along the path 2 are less favorable by $20 \mathrm{kcal} \cdot \mathrm{mol}^{-1}$. Importantly, the additional stabilization of zwitterion forms may be caused by the interaction of two molecules in the appropriate orientation (the formation of molecular associate).

Thus, it follows from the results of quantum-chemical modeling that the most energetically favorable for the molecules of calix[4]resorcines in the solution containing free aminoalkyl groups are the protonated forms of nitrogen atoms of amine groups.

\section{pH-Metrical Study of $\boldsymbol{L}$}

Using the method of $\mathrm{pH}$ titration and the data of quantum-chemical modeling on the example of calix[4] resorcine $\mathbf{L}$ we have studied the possible centers of proton separation. The investigated compound $\mathbf{L}$ is soluble in $\mathrm{H}_{2} \mathrm{O}$; and more restrictedly soluble in $\mathrm{EtOH}$ and $\mathrm{Me}_{2} \mathrm{CO}$. 


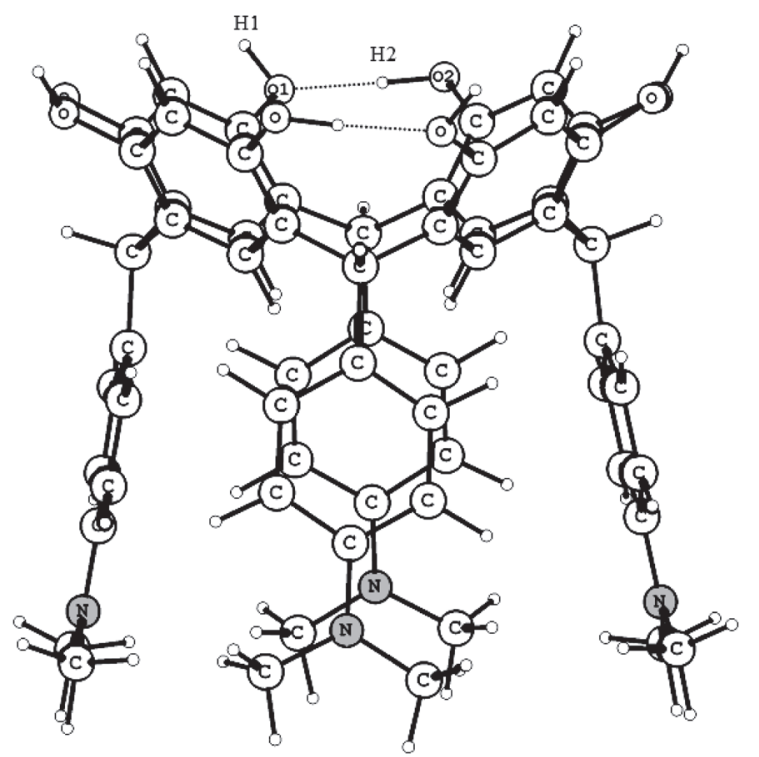

Figure 2a. The optimized geometry of $\mathbf{L}$ in ethanol shows the average distances $\mathrm{r}(\mathrm{O} 1-\mathrm{H} 1)=0.980 \AA, \mathrm{r}(\mathrm{O} 1-\mathrm{H} 2)=1.661 \AA$, $\mathrm{r}(\mathrm{O} 2-\mathrm{H} 2)=1.002 \AA$ for the selected group of atoms.

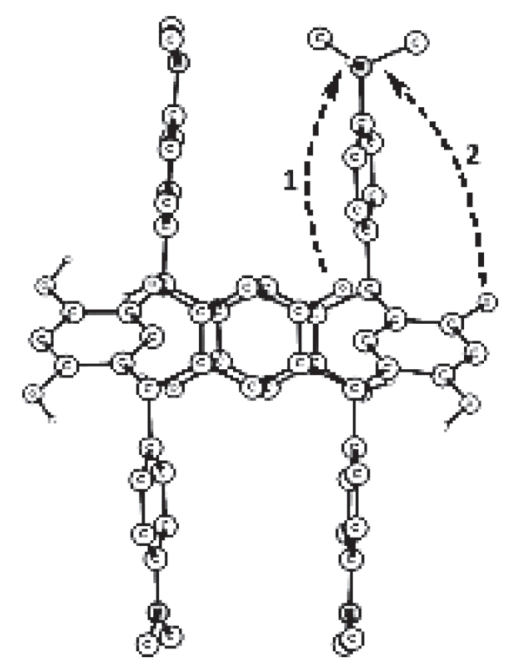

Figure 2c. Ways of proton transfer from different hydroxyl groups to nitrogen atoms of the amino groups in the formation of zwitterionic form $\mathbf{L}$ '.

Figure 3 shows the curves of $\mathrm{pH}$-metric titration of the solutions $\mathbf{L}$ and $\mathrm{H}_{2} \mathrm{O}$, EtOH, $\mathrm{Me}_{2} \mathrm{CO}$, treatment of which was carried out according to the work. ${ }^{[22]}$

Here, the number of the titrated $n$ protons is equal to the number of $\mathrm{KOH}$ moles, related to the number of $\mathbf{L}$ moles. Hence, $n$ would correspond to the equivalence points. It follows from the graphs $3 \mathrm{a}, 3 \mathrm{~b}, 3 \mathrm{c}$ that on titrating $\mathbf{L}$ in $\mathrm{H}_{2} \mathrm{O}$, EtOH and $\mathrm{Me}_{2} \mathrm{CO}$, these values are equal respectively to $2.5,4.0,1.0$.

At the titration process, there may be titrated the amino groups and the protons of resorcinol groups, however, with the account of the data of quantum chemical simulation, we believe that since the protonation of the nitrogen atoms of the amino groups is the most energetically favorable and,

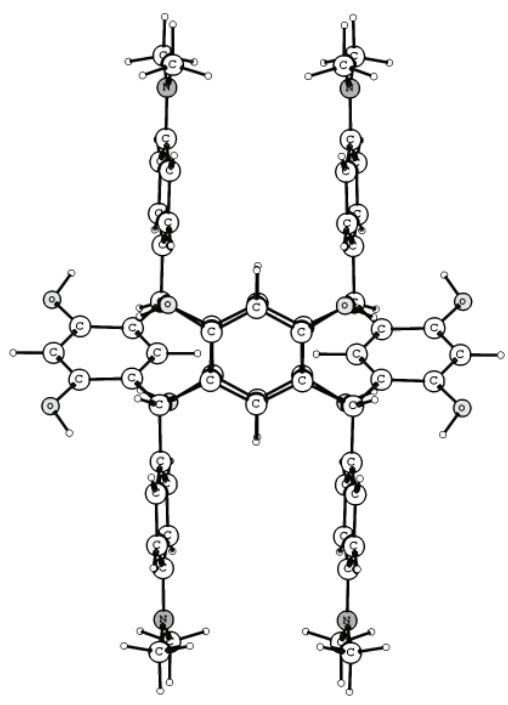

Figure 2b. The optimized geometry of the structure $\mathbf{L}$ ' in EtOH: the «front view».

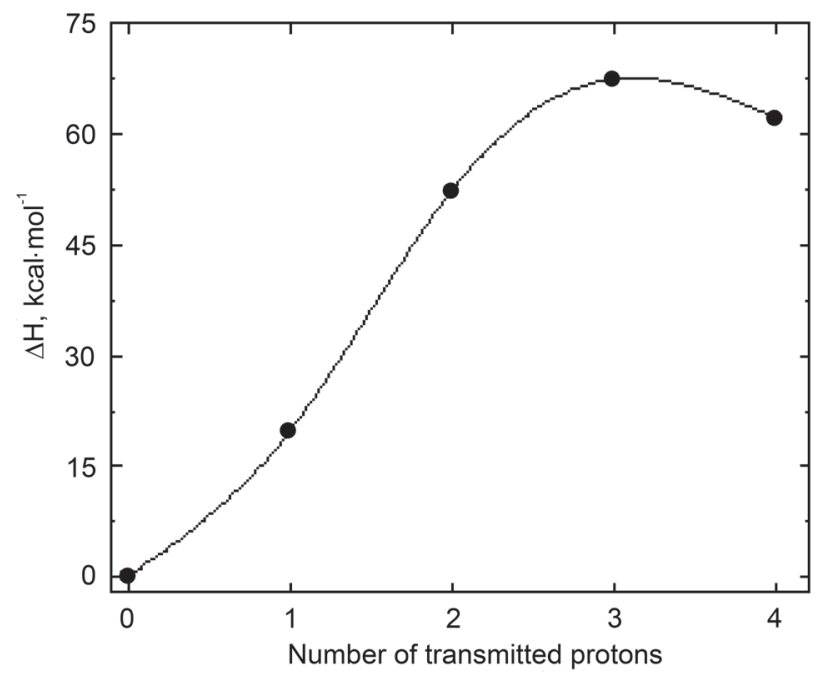

Figure 2d. The dependence of total energy of zwitter-ionic forms of the ligand on the number of protons transported along the path 1 (see Figure 1c). As a point of reference there is taken the full energy of 'L'.

therefore, a preferential process, the cleavage of protons during titration is carried out primarily from the resorcinol groups.

In the process of $\mathbf{L}$ titration in water (Figure $3 \mathrm{a}$ ) at the region $\mathrm{pH}=3-7$, five protons can be cleaved. The cleavage of four protons will take place from the resorcinol groups of a single molecule of $\mathbf{L}$, the fifth proton can be cleaved from the protonated aminogroup. However, based on quantum chemical simulation data, the fifth proton is likely to be cleaved from the hydroxyl group of the second molecule of the compound. In this case, as we see it, at the region of $\mathrm{pH}=$ $3-7, \mathbf{L}$ in $\mathrm{H}_{2} \mathrm{O}$ can exist in cationic form as a dimer:

$$
2\left(\mathrm{H}_{12} \mathrm{~L}\right)^{4+} \rightleftarrows\left(\mathrm{H}_{24} \mathrm{~L}_{2}\right)^{8+} \rightleftarrows\left(\mathrm{H}_{19} \mathrm{~L}_{2}\right)^{3+}+5 \mathrm{H}^{+} .
$$

Макрогетерочииклы / Macroheterocycles 2015 8(4) 415-423 


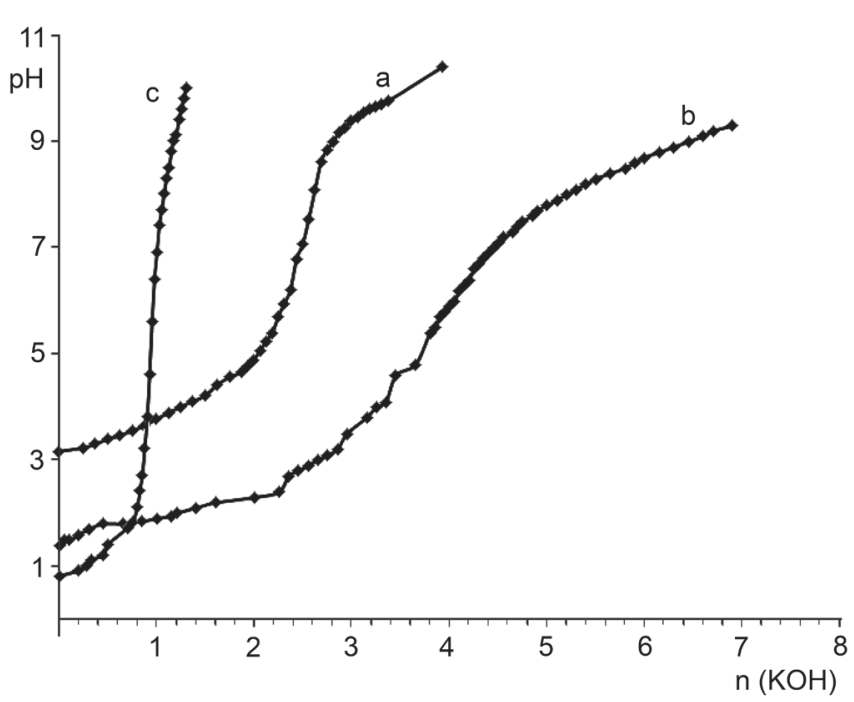

Figure 3. Curves of $\mathrm{pH}$-metric titration of the systems $\left.\left(\mathrm{V}_{\mathrm{L}}=20 \mathrm{ml}\right): \mathrm{a}\right) \ll \mathbf{L}-\mathrm{H}_{2} \mathrm{O} », C_{\mathrm{L}}=2 \cdot 10^{-3} \mathrm{M}, C_{\mathrm{con}}=5 \cdot 10^{-3} \mathrm{M}$; b) $\left\langle\mathbf{L}-\mathrm{EtOH} », C_{\mathrm{L}}=2 \cdot 10^{-3} \mathrm{M}, C_{\text {con }}=4 \cdot 10^{-3} \mathrm{M}\right.$;

c) $\ll \mathbf{L}-\mathrm{Me}_{2} \mathrm{CO} »: C_{\mathrm{L}}=2 \cdot 10^{-3} \mathrm{M}, C_{\text {con }}=4 \cdot 10^{-3} \mathrm{M}$.

In the process of titrating $\mathbf{L}$ in $\mathrm{EtOH}$ at the $\mathrm{pH}=2-6$ region, four protons are cleaved (Figure $2 b$ ). Therefore, in the indicated region of $\mathrm{pH}, \mathbf{L}$ in $\mathrm{EtOH}$, probably, will exist in the form of the neutral monomer:

$$
\left(\mathrm{H}_{12} \mathrm{~L}\right)^{4+} \rightleftarrows\left(\mathrm{H}_{8} \mathrm{~L}\right)+4 \mathrm{H}^{+}, \mathrm{pH}=2-6 .
$$

On titrating $\mathbf{L}$ in acetone in $\mathrm{pH} \sim 1-7$ region, one proton is cleaved (Figure 2c). Consequently, it is possible that in the region of $\mathrm{pH} \leq 7$ in $\mathrm{Me}_{2} \mathrm{CO}, \mathbf{L}$ is present in the form of a cation:

$$
\left(\mathrm{H}_{12} \mathrm{~L}\right)^{4+} \rightleftarrows\left(\mathrm{H}_{11} \mathrm{~L}\right)^{3+}+\mathrm{H}^{+}, \mathrm{pH}=1-7 .
$$

Thus, it follows from the data of quantum-chemical modeling and $\mathrm{pH}$-metry that $\mathbf{L}$ in $\mathrm{Me}_{2} \mathrm{CO}$ and in $\mathrm{H}_{2} \mathrm{O}$ at the region $\mathrm{pH} \leq 7$ is in the form of protonated cation monomer $\left(\mathrm{Me}_{2} \mathrm{CO}\right)$ or dimer $\left(\mathrm{H}_{2} \mathrm{O}\right)$. In EtOH at the region of $\mathrm{p} H \leq 6, \mathbf{L}$ is in the form of a neutral monomer, but this does not exclude the presence of protonated amino groups of the lower rim. The protonated forms of the amino groups lead to the formation of a positively charged lower rim, and the partial or total deprotonation of the upper rim formed by the resorcinol groups result in the formation of resorcinolate forms. The combination in the molecule of oppositely charged groups should contribute to the spontaneous formation of associates by ectrostatic mechanism of the type "head to tail". Due to the high ionizing properties of $\mathrm{Me}_{2} \mathrm{CO}$ and $\mathrm{H}_{2} \mathrm{O}$ one should not exclude the possibility of forming heteromolecular associates, which hold the solvent molecules by means of hydrogen bonds of the type:

1) $(\mathrm{Me})_{2}-\mathrm{C}^{\delta+}=\mathrm{O}^{\delta-} \leftrightarrow \mathrm{H} \cdots \mathrm{N}(\mathrm{Me})_{2} \mathrm{Ar}-$;

2) $(\mathrm{Me})_{2}-\mathrm{C}^{\delta+}=\mathrm{O}^{\delta-\cdots} \cdot \mathrm{H}^{\delta+}-\mathrm{O}^{\delta-}-\mathrm{Rez}$;

3) $\mathrm{H}_{2} \mathrm{O}^{\delta-} \leftrightarrow \mathrm{H} \cdots \mathrm{N}(\mathrm{Me})_{2} \mathrm{Ar}-$;

4) $\mathrm{H}_{2} \mathrm{O}^{\delta-\cdots} \cdot \mathrm{H}^{\delta+}-\mathrm{O}^{\delta-}-\mathrm{Rez}$.

\section{Electron Spectroscopy and Conductometry of $\boldsymbol{L}$}

We have studied the electronic absorption spectra of $\mathbf{L}$ solutions in $\mathrm{H}_{2} \mathrm{O}$, EtOH and $\mathrm{Me}_{2} \mathrm{CO}$ at different concentrations.

Figure 4.I shows the EAS of $\mathbf{L}$ in $\mathrm{EtOH}$ in the interval 200-800 nm for a number of the studied concentrations $\left(C_{\mathrm{L}} \cdot 10^{-3} \mathrm{M}: 5\right.$ (1); $\left.2.5(2), 1.25(3) ; 0.725(4)\right)$.

Bands at the region of 200-300 nm (Figure 4.I-2) are determined by $\pi \rightarrow \pi^{*}$ electron transitions in the chromophores (aryl rings of calixresorcine matrix and substituents). The intensity of the benzene bands $\left(\lambda_{\text {max }} \sim 228,275 \mathrm{~nm}\right)$ is increased by the presence of auxochromes adjacent to $\sigma$-bonds (oxygen atoms in $\mathrm{Rez}-\mathrm{OH}$, nitrogen atoms in $\mathrm{Ar}-\mathrm{NMe}_{2}$ ) and favoring the emergence of $n \rightarrow \sigma^{*}$ transitions. Furthermore, under the protonation condition of amino groups the unshared electron pair (UEP) on the nitrogen atom is not capable of reacting with $\pi$-electron density of the benzene ring so EAS of the protonated aminoaryl radical is close to EAS of benzene. However, deprotonation of Rez-OH fragments is accompanied by the appearance of the negative charge on the oxygen atom. As a result, the bands of charge transfer at the region of 300-400 nm undergo a bathochromic shift ( $\sim 309$, $349,368,395 \mathrm{~nm}$ ) with hyperchromic effect. ${ }^{[23,24]}$

With the reduction of the substance concentration in ethanol (Figure 4.I-3,4) the intensity of the absorption bands is reduced, but their character and position of the maxima at the region of $200-400 \mathrm{~nm}$ changes insignificantly. The increase of concentration (Figure 4.I-1) is accompanied by the cleavage of each of the absorption bands at the region 300-400 nm to 2-3 components and 9 absorption bands are present in EAS $(310,317,328,342,355,366,376,383,398$ $\mathrm{nm})$. Such spectral changes are due to exciton interaction of transition dipoles arranged in parallel planes to form various excited electronic energy levels.

These multiplets are observed in molecules containing more than one molecule in the unit cell. ${ }^{[25]}$ This fact indicates that the flow of association processes of $\mathbf{L}$ molecules with increasing concentrations of $\mathrm{EtOH}$; a similar pattern is also observed in $\mathrm{Me}_{2} \mathrm{CO}$ at $C_{\mathrm{L}}=5 \cdot 10^{-3} \mathrm{M}$ (Figure 4.I-1).

It should be noted that the absorption at the region of 200-300 nm in EtOH, $\mathrm{H}_{2} \mathrm{O}$ and $\mathrm{Me}_{2} \mathrm{CO}$ is influenced by solvents, and at the region of $300-350 \mathrm{~nm}$ in $\mathrm{Me}_{2} \mathrm{CO}$ the influence of solvents is also observed. ${ }^{[23]}$

The absorption bands in EAS of $\mathbf{L}$ solutions in acetone are significantly broadened and shifted, because they lie in the same region as the absorption band of the solvent itself. In $\mathrm{H}_{2} \mathrm{O}$, there is observed the broadening at the region of less than $300 \mathrm{~nm}$, which is usually the edge of the fundamental absorption band for $\mathrm{H}_{2} \mathrm{O}$ (Figure 4.II-1).

Organization of individual molecules $\mathbf{L}$ in the investigated solvents is also studied by conductometry. To this end the concentration dependences of the electrical conductivity are obtained for $\mathbf{L}$ solutions in $\mathrm{H}_{2} \mathrm{O}$, EtOH, $\mathrm{Me}_{2} \mathrm{CO}$ (Figure 5). ${ }^{[4]}$

Apparently, the nature of changes of the concentration dependence of $\mathbf{L}$ electrical conductivity in $\mathrm{H}_{2} \mathrm{O}, \mathrm{EtOH}$ and $\mathrm{Me}_{2} \mathrm{CO}$ (Figure 5) is typical for ionogenic surface active substances (SAS).

It has been found that with the increase of $\mathbf{L}$ content in the studied solvents even at low concentrations, there is 


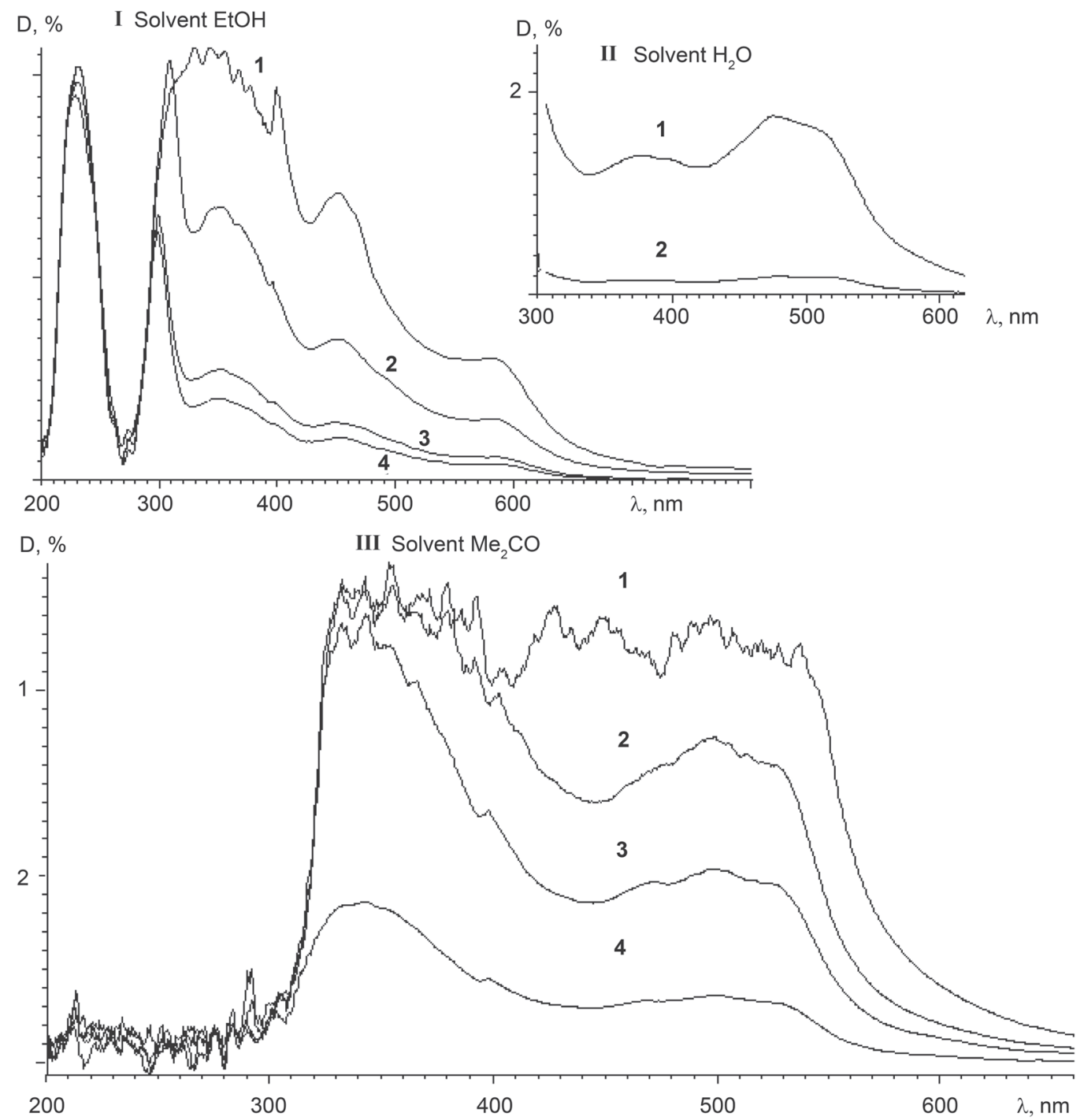

Figure 4. EAS of the system I - «L - EtOH»: 200-700 nm; $C_{\mathrm{L}} \cdot 10^{-3} \mathrm{M}: 5$ (1); 2.5 (2), 1.25 (3); 0.725 (4); II - EAS of the system «L $-\mathrm{H}_{2} \mathrm{O} »: 300-600 \mathrm{~nm} ; C_{\mathrm{L}} \cdot 10^{-3} \mathrm{M}: 1.25$ (1); 0.725 (2); III - EAS of the system «L $-\mathrm{Me}_{2} \mathrm{CO} »: 200-700 \mathrm{~nm} ; C_{\mathrm{L}} \cdot 10^{-3} \mathrm{M}: 5$ (1); 2.5 (2), $1.25(3) ; 0.725(4)$.

a sharp increase in the electrical conductivity associated, apparently, with the number of protonated molecules of calix resorcinols before inflection, corresponding to the critical concentration of association (CCA). In the region of these concentrations, there is beginning to emerge spontaneously the associates by electrostatic mechanism of the type "head to tail", most likely in the form of ionic micelles. Thereafter, the ion mobility decreases and therefore, the electrical conductivity decreases.

Values of $\mathrm{CCA}_{1}$ in $\mathrm{H}_{2} \mathrm{O}$ and $\mathrm{Me}_{2} \mathrm{CO}$ have similar amounts: correspondingly $\sim 0.13 \cdot 10^{-3} \mathrm{M}$ and $\sim 0.16 \cdot 10^{-3} \mathrm{M}$ ) (Figure 5a, 5c). In EtOH, when association starts, a relatively small interval of concentration is observed $(\sim 0.03-0.30) \cdot 10^{-3}$ $\mathrm{M}$, where the electrical conductivity increases sharply, then there is a very sharp drop to $\sim 2.5 \cdot 10^{-3} \mathrm{M}$ (Figure $5 \mathrm{~b}$ ).

In $\mathrm{H}_{2} \mathrm{O}$ and $\mathrm{Me}_{2} \mathrm{CO}$ a different picture is observed. After $\mathrm{CCA}_{1}$ there is observed a gradual increase of the electrical conductivity. In $\mathrm{H}_{2} \mathrm{O}$ (Figure $5 \mathrm{a}$ ) after $\mathrm{CCA}_{1} \sim 0.13 \cdot 10^{-3} \mathrm{M}$, there are still some more inflections, corresponding to
$\mathrm{CCA}_{2} \sim 0.4 \cdot 10^{-3} \mathrm{M}, \mathrm{CCA}_{3} \sim 1.2 \cdot 10^{-3} \mathrm{M}$ and $\mathrm{CCA}_{4} \sim 2.0 \cdot 10^{-3} \mathrm{M}$. In $\mathrm{Me}_{2} \mathrm{CO}$ (Figure 5c) after $\mathrm{CCA}_{1}$ there is also a gradual increase of the electrical conductivity, but there is only one inflection corresponding to $\mathrm{CCA}_{2} \sim 4.5 \cdot 10^{-3} \mathrm{M}$.

\section{The Dynamic Light Scattering}

Another indication of self-association and the formation of aggregates at the region $C \geq(0.03 \sim 5.2) \cdot 10^{-3} \mathrm{M}$ is the data of DLS. Generally, aggregated particles at standing undergo partial hardening due to the formation of the spaces - the grid structure of coagulation. ${ }^{[26]}$ As a result of ultrasonic mixing (UM) these coagulated particles are subjected to peptization and distributed in the bulk solution.

For the solution of $\mathbf{L}$ in $\mathrm{H}_{2} \mathrm{O}$ without $\mathrm{UM}$, there is no diagram of size distribution. After UM (Figure 6a) there is observed a bimodal size distribution by the number of particles, characterized by the corresponding average hydrodynamic diameter $\sim 115 \mathrm{~nm}$ and $\sim 788 \mathrm{~nm}$, characteristic 

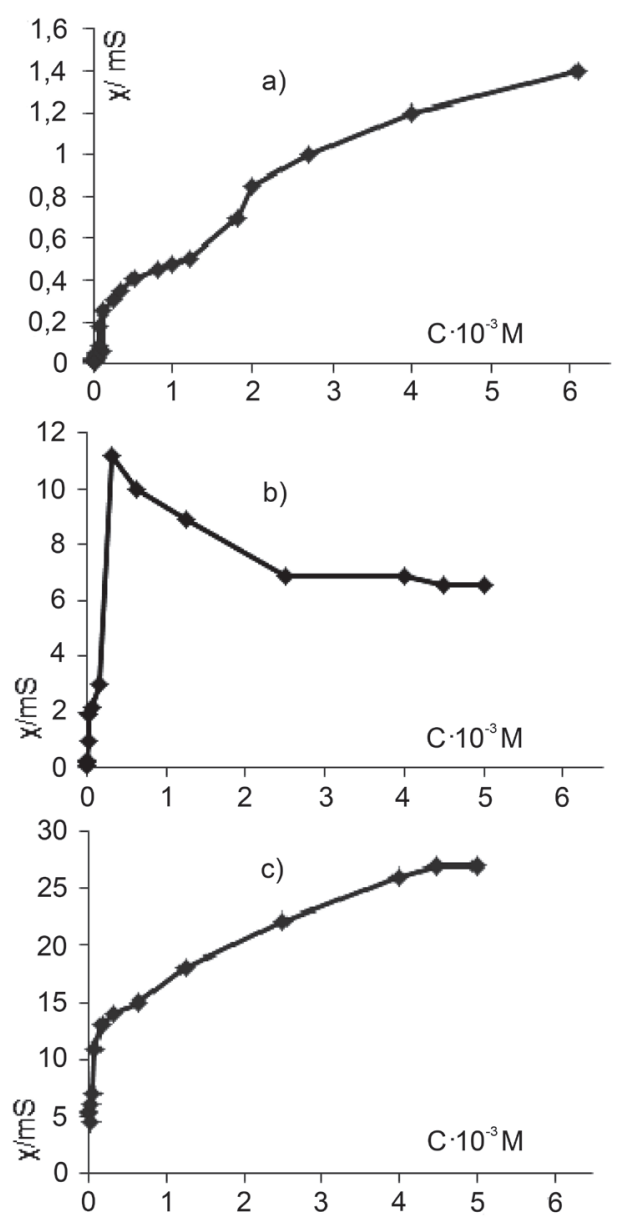

Figure 5. The concentration dependences of the electrical conductivity $\chi$ of $\mathbf{L}$ solutions in $\mathrm{H}_{2} \mathrm{O}$ (a), $\mathrm{EtOH}(\mathrm{b}), \mathrm{Me}_{2} \mathrm{CO}$ (c).

of the micro-heterogeneous environments. The solution contains mainly larger particles $(\sim 87 \%)$ of the second fraction.

With the reduction of $\mathrm{H}_{2} \mathrm{O}$ up to 20 vol. $\%$ in the system water-acetone (Figure $6 \mathrm{~b}$ ) or 100 vol. \% (Figure $6 \mathrm{c}$ ) in the solutions of $\mathbf{L}$ both before and after UM there is observed a bimodal distribution of sizes by the number of particles, characterized by the average hydrodynamic diameters $\sim 188$ $\mathrm{nm}(10 \%), \sim 1101 \mathrm{~nm}(90 \%)$ and $276 \mathrm{~nm}(0.55 \%), \sim 5635$ $\mathrm{nm}(99.45 \%)$, respectively. The increase of $\mathrm{Me}_{2} \mathrm{CO}$ content in the system leads to increase of volume fraction of large particles, respectively up to $90 \%$ and $99 \%$.

Phenomena associated with the enlargement of the $\mathbf{L}$ particles with increasing the content of $\mathrm{Me}_{2} \mathrm{CO}$ is due to the fact that the latter as a strongly ionizing aprotic solvent tends mainly to the formation of heteromolecular hydrogen bonds. Therefore, the increase of its content in the solution promotes the formation of new hydrogen bonds accompanied by the increase in the number of heteromolecular associates and aggregation. Consequently, $\mathrm{Me}_{2} \mathrm{CO}$ may be involved in various types of interactions with different groups in $\mathbf{L}$ :

1) $(\mathrm{Me})_{2}-\mathrm{C}^{\delta+}=\mathrm{O}^{\delta-} \leftrightarrow \mathrm{H} \cdots \mathrm{N}(\mathrm{Me})_{2}-\mathrm{Ar}$

2) $(\mathrm{Me})_{2}-\mathrm{C}^{\delta+}=\mathrm{O}^{\delta} \cdots \mathrm{H}^{\delta+}-\mathrm{O}^{\delta-}-\mathrm{Rez}$

In addition, the formation of associates proceeds without the participation of a solvent by electrostatic interaction between the positively charged protinted lower rim and the negatively charged upper rim formed by a cleavage of a proton - "head to tail." Thus, the association of $\mathbf{L}$ molecules in $\mathrm{Me}_{2} \mathrm{CO}$ occurs in two planes: between the molecules of calixresorcines, and between the molecules of calixresorcines and solvent that results in substantial enlargement of the particles. The presence of two CCA on the concentration dependences of the electrical conductivity confirms the data of DLS.

With reducing in the system content of $\mathrm{H}_{2} \mathrm{O}$ up to $20 \mathrm{vol}$. $\%$ while increasing the share of EtOH up to 80 vol. \% there is also observed a bimodal size distribution by the number of particles (Figure 6d) with preferential predominance ( 91\%) of larger particles with average dimensions of about $591 \mathrm{~nm}$. The increase of $\mathrm{EtOH}$ in the content up to 100 vol. \% results in further consolidation of the particles ( $\mathrm{R} \sim 3452 \mathrm{~nm}$ ), but there is observed a monomodal size distribution on the number of particles $\mathbf{L}$, before and after UM (Figure 6e), indicating the formation of a monodisperse system. $\mathrm{EtOH}$ as well as $\mathrm{Me}_{2} \mathrm{CO}$ indicates the formation of a monodisperse system $\mathbf{L}$ :

1) $\mathrm{EtO}^{\delta-} \leftrightarrow \mathrm{H}^{\cdots} \cdot \mathrm{N}(\mathrm{Me})_{2}-\mathrm{Ar}$ or

2) $\mathrm{EtO}^{\delta-\cdots} \cdot \mathrm{H}^{\delta+}-\mathrm{O}^{\delta-}-\mathrm{Rez}$.

Since EtOH is less ionized, the tendency for the formation of hetero-molecular associates is expressed very poor; more preferred is a two-dimensional grid formation of intermolecular hydrogen bonds between the molecules of $\mathrm{EtOH}$, which does not promote the consolidation of the associates formed.

Then, basically, self-association of $\mathbf{L}$ molecules with the formation of ionic micelles of the type "head to tail" due to the electrostatic interactions of the positively charged lower protonated rim and negatively charged upper rim formed at the expense of proton cleavage will be preferable. Therefore, in the EtOH, self-association of $\mathbf{L}$ molecules proceeds mainly at one plane - between the molecules of the calixresorcinols that does not contribute to the enlargement of the particles. The presence of a sharp increase in the electrical conductivity and a sharp drop after CCA confirms the data of DLS. Apparently, the predominant single component association between $\mathbf{L}$ molecules promotes the formation of monodisperse system with homogeneous symmetrical units. Thus, the $\mathrm{H}_{2} \mathrm{O}$ increase in the content in the system promotes the formation of smaller particles; increase in the proportion of nonaqueous solvent leads conversely to the enlargement (coagulation) of the particles in the system.

The tendency to form a two-dimensional grid of intermolecular hydrogen bonds between the molecules for the $\mathrm{H}_{2} \mathrm{O}$ is expressed in greater degree than for ethanol.

In addition, the higher ionizing ability compared to $\mathrm{EtOH}$, promotes the interaction of the type:

1) $\mathrm{H}_{2} \mathrm{O}^{\delta-} \leftrightarrow \mathrm{H} \cdots \mathrm{N}(\mathrm{Me})_{2}-\mathrm{Ar}$ or

2) $\mathrm{H}_{2} \mathrm{O}^{\delta-\cdots} \cdot \mathrm{H}^{\delta+}-\mathrm{O}^{\delta-}-\mathrm{Rez}$.

At the same time for $\mathbf{L}$ there is observed a significant solubility in $\mathrm{H}_{2} \mathrm{O}$. In combination with small size and more pronounced ionizing properties (dielectric permittivity $\sim 78$ ), the given facts explain, on the one hand, the formation 

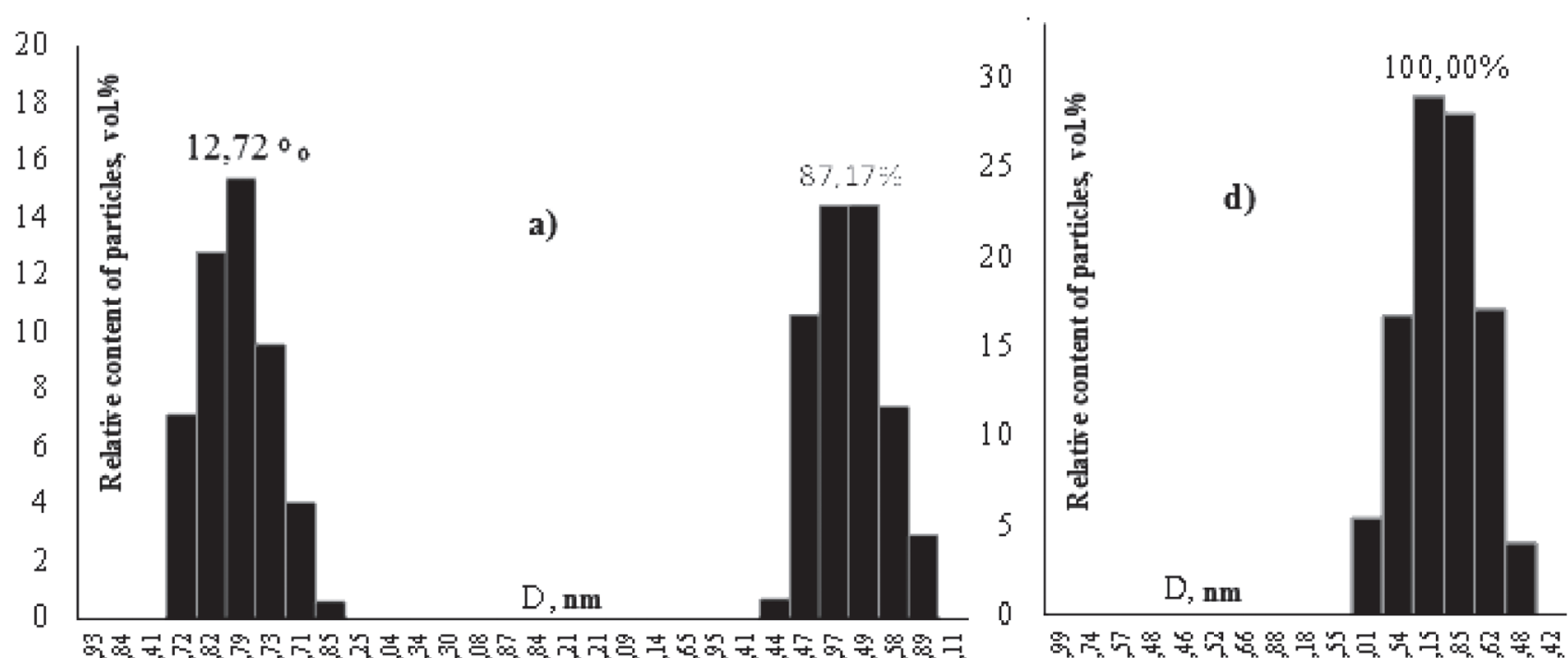

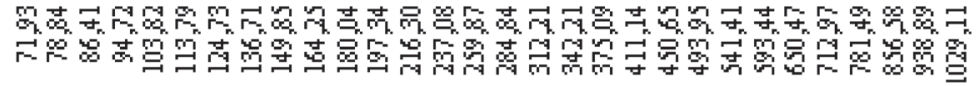

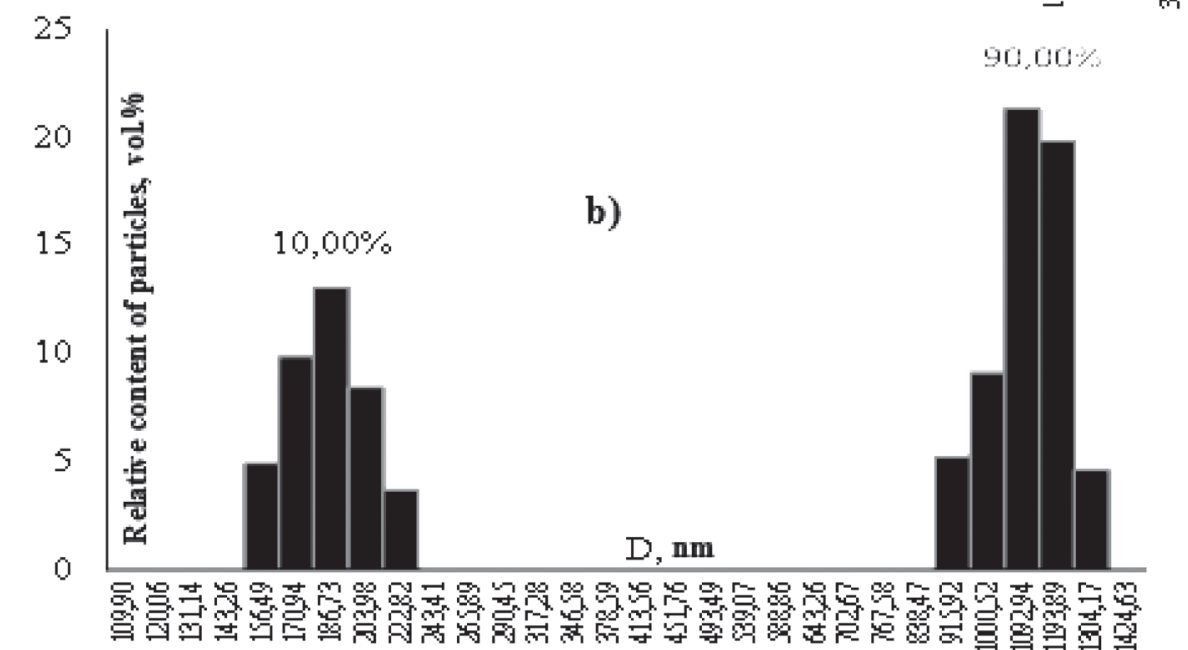

$\mathrm{g}_{\mathrm{r}} \mathrm{F}$

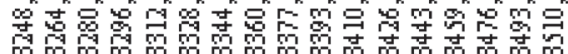
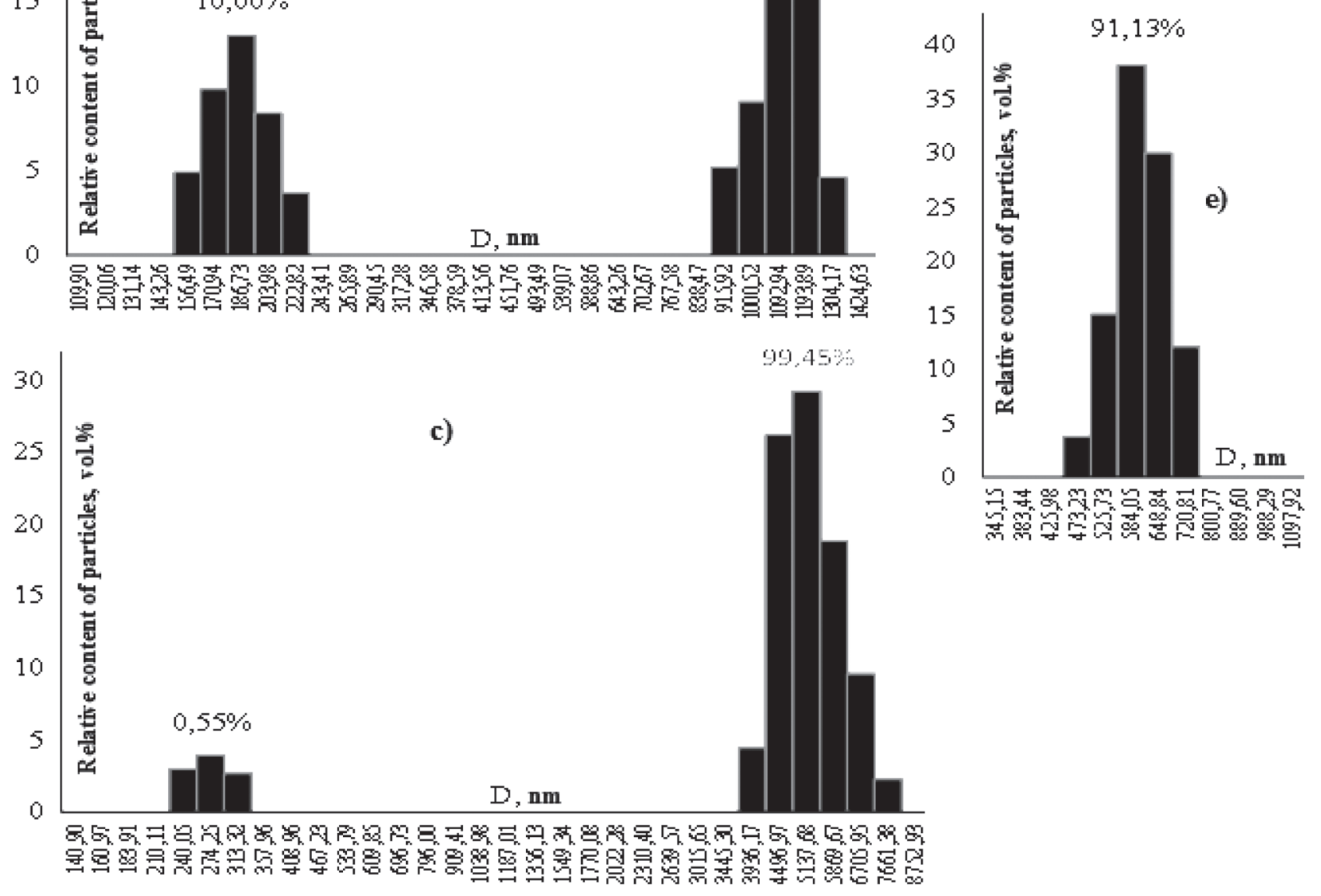

Figure 6. Results of DLS: a) $\mathbf{L}+\mathrm{H}_{2} \mathrm{O}\left(100\right.$ vol. \%), with UM; b) $\mathbf{L}+\mathrm{H}_{2} \mathrm{O}\left(20\right.$ vol. \%) $+\mathrm{Me}_{2} \mathrm{CO}$, before and after UM; c) $\mathbf{L}+\mathrm{Me}{ }_{2} \mathrm{CO}(100$ vol. \%), before and after UM; d) $\mathbf{L}+\mathrm{H}_{2} \mathrm{O}(20 \mathrm{vol} . \%)+\mathrm{EtOH}$, before and after UM; e) L + EtOH (100 vol. \%), before and after UM. 
of smaller associated particles in $\mathrm{H}_{2} \mathrm{O}$, and, on the other hand, a greater number of opportunities for structuring. Therefore, on the concentration dependences of the electrical conductivity of $\mathbf{L}$ in $\mathrm{H}_{2} \mathrm{O}$, there are observed more points of $\mathrm{CCA}$ than in $\mathrm{EtOH}$ and $\mathrm{Me}_{2} \mathrm{CO}$.

\section{Conclusions}

Thus, the complex of physical and chemical methods has shown the preferential protonation of the amino groups of the lower rim and dissociation from hydroxogroups of upper rim of aminomethylated calix[4]resorcine $\mathbf{L}$ that accounts for its self-association of the type "head to tail" in $\mathrm{Me}_{2} \mathrm{CO}, \mathrm{EtOH}$ and $\mathrm{H}_{2} \mathrm{O}$ due to electrostatic interaction. More powerful ionizing properties of $\mathrm{Me}_{2} \mathrm{CO}$ and $\mathrm{H}_{2} \mathrm{O}$ contribute to the formation of two-component assemblies with solvent molecules, as evidenced by the gradual increase in the electrical conductivity. The tendency to the formation of intermolecular hydrogen bonds between the molecules of the solvent promotes the formation of a homogeneous monodisperse medium in the case of EtOH. More pronounced ionizing properties of $\mathrm{H}_{2} \mathrm{O}$, despite the tendency to form intermolecular hydrogen bonds between the water molecules, prevent the formation of a homogeneous medium and enlargement of particles. It has been found that in contrast to an aqueous, nonaqueous media contribute to the enlargement of associates of aminomethylated calix[4]resorcine $\mathbf{L}$. The conformational differences of aminocalix[4]resorcine affect the possibility of the formation of zwitter-ionic forms.

\section{References}

1. Gutsche C.D. Calixarenes: An Introduction (2) (Stoddard J.Fr., Ed.). London: Royal Society of Chemistry, 2008. 276 p.

2. Jain V.K., Kanaiya P.H. Russ. Chem. Rev. 2011, 80, 77-106.

3. Arnott G., Hunter R., Su H. Tetrahedron 2006, 62, 977-991.

4. Pashirova T.N., Lukashenko S.S., Kosacheva E.M., Leonova M.V., Vaganova L.I., Burilov A.R., Pudovik M.A., Kudryavtseva L.A., Konovalov A.I. Russ. J. Gen. Chem. 2008, 78, 402-409.

5. Arnott G., Hunter R. Tetrahedron 2006, 62, 992-1000.

6. Ngodwana L., Kleinhans D.J., Smuts A.-J., Otterlo W.A.L., Arnott G.E. RSC Adv. 2013, 3, 3873-3876.

7. Jain V.K., Pillai S.G., Gupte H.S. J. Iran. Chem. Soc. 2008, 5, 646-656.

8. Podyachev S.N., Burmakina N.E., Syakaev V.V., Sudakova S.N., Shagidullin R.R., Konovalov A.I. Tetrahedron 2009, 65, 408-417.

9. Sugden M.W., Richardson T.H., Davis F., Higson S.P.J., Faul C.F.J. Colloids Surf. A 2008, 321, 43-46.

10. Biros Sh.M., Rebek J.Jr. Chem. Soc. Rev. 2007, 36, 93-104.

11. Guseva E.V., Morozov V.I., Gavrilova E.L., Shatalova N.I., Grishin E.I. Russ. J. Gen. Chem. 2011, 81, 2039-2044.

12. Guseva E.V., Morozov V.I., Zinkicheva T.T., Voloshina E.I., Grishin E.I. Russ. J. Gen. Chem. 2012, 82, 1323-1333.
13. Guseva E.V., Grishin E.I., Gavrilova E.L. Vestnik Kazan. Tekhnol. Univers. 2013, 16, 13-20 (in Russ.).

14. Saenger W., Betzel C., Hingerty B., Brown G.M. Angew. Chem. Int. Ed. 1983, 22, 883-884.

15. Mäkinen M., Vainiotalo P., Rissanen K. J. Am. Soc. Mass Spectrom. 2002, 13, 851-861.

16. Yanilkin V.V., Ryzhkina I.S., Nastapova N.V., Pashirova T.N., Babkina Ya.A., Burilov A.R., Morozov V.I., Konovalov A.I. Russ. Chem. Bull. Int. Ed. 2003, 52, 1142-1149.

17. Frisch M.J., Trucks G.W., Schlegel H.B., Scuseria G.E., Robb M.A., Cheeseman J.R., Montgomery J.A., Vreven Jr.T., Kudin K.N., Burant J.C., Millam J.M., Iyengar S.S., Tomasi J., Barone V., Mennucci B., Cossi M., Scalmani G., Rega N., Petersson G.A., Nakatsuji H., Hada M., Ehara M., Toyota K., Fukuda R., Hasegawa J., Ishida M., Nakajima T., Honda Y., Kitao O., Nakai H., Klene M., Li X., Knox J.E., Hratchian H.P., Cross J.B., Adamo C., Jaramillo J., Gomperts R., Stratmann R.E., Yazyev O., Austin A.J., Cammi R., Pomelli C., Ochterski J.W., Ayala P.Y., Morokuma K., Voth G.A., Salvador P., Dannenberg J.J., Zakrzewski V.G., Dapprich S., Daniels A.D., Strain M.C., Farkas O., Malick D.K., Rabuck A.D., Raghavachari K., Foresman J.B., Ortiz J.V., Cui Q., Baboul A.G., Clifford S., Cioslowski J., Stefanov B.B., Liu G., Liashenko A., Piskorz P., Komaromi I., Martin R.L., Fox D.J., Keith T., Al-Laham M.A., Peng C.Y., Nanayakkara A., Challacombe M., Gill P.M.W., Johnson B., Chen W., Wong M.W., Gonzalez C., Pople J A. Gaussian 03, Revision B.04. Gaussian, Inc., Pittsburgh PA, 2003.

18. Hehre W.J., Radom L., Schleyer P.v.R., Pople J.A. Ab initio Molecular Orbital Theory, N.Y.: J. Willey \& Sons, 1986. 548 p.

19. Nazmutdinov R.R., Roznyatovskaya N.V., Glukhov D.V., Manyurov I.R, Mazin V.M., Tsirlina G.A., Probst M. Inorg. Chem. 2008, 47, 6659-6673.

20. Nazmutdinov R.R., Bronshtein M.D., Zinkicheva T.T., Chi Q., Zhang J., Ulstrup J. Phys. Chem. Chem. Phys. 2012, 14, 5953-5965.

21. Alexandrov V.V. Acidity of Nonaqueous Solvents. Kharkiv: Vishcha shkola, 1981. 152 p. (in Russ.) [Александров В.В. Кислотность неводных растворов. Харьков: Выща школа, 1981. 152 c.].

22. Sapin R., Munshi K.N. J. Inorg. Nucl. Chem. 1972, 34, 581590.

23. Sverdlova O.V. Electronic Spectra in Organic Chemistry. Leningrad: Chemistry, 1985. 248 p. (in Russ.) [Свердлова О.В. Электронные спектры в органической химии. Л.: Химия, 1985. 248 с.].

24. Vasilev A.V. Introduction to Spectroscopy. St. Petersburg: $\mathrm{SPbSU}$, Institute of Chemistry, http://www.chem.spbu. ru/org/897 (checked 09.08.15) (in Russ.) [Васильев А.В. Введение в спектроскопию. СПб: СПбГУ, Институт химии].

25. Broude V.L., Rashba E.I., Sheka E.F. Spectroscopy of Molecular Excitons. Moscow: Energoizdat, 1981. 248 p. (in Russ.) [Броуде В.Л., Рашба Э.И., Шека Е.Ф. Спектроскопия молекулярных экситонов. М.: Энергоиздат, 1981. 248 с.].

26. Encyclopedic Dictionary of Mathematics (Prokhorov A.V., Ed.). Moscow: Soviet Encyclopedia, 1988. 848 p. (in Russ.) [Математический энщиклопедический словарь (Прохоров Ю.В., ред.). М.: Сов. энциклопедия, 1988. 848 с.]. 